\title{
PEMANFAATAN EKSTRAK BATANG BUAH NENAS UNTUK KUALITAS MINYAK KELAPA
}

\author{
Meiske S. Sangi ${ }^{1)}$ \\ ${ }^{1)}$ Program Studi Kimia FMIPA Universitas Sam Ratulangi Manado, 95115 \\ e-mail: meiske_sangi@yahoo.co.id
}

\begin{abstract}
ABSTRAK
Telah dilakukan penelitian pemanfaatan ekstrak batang buah nanas untuk kualitas minyak kelapa. Pengolahan minyak kelapa masih banyak dilakukan secara tradisional oleh masyarakat, khususnya masyarakat yang tinggal di pedesaan. Adanya perkembangan teknologi minyak kelapa yang diolah secara tradisional bersaing dengan minyak kelapa yang ada di pasaran. Untuk mengatasi hal ini diperlukan metode yang dapat menghasilkan minyak yang berkualitas dengan daya simpan yang lama dan memberikan aroma yang disukai. Penelitian ini bertujuan untuk menentukan perbandingan berat batang buah nanas dan daging buah kelapa serta waktu pemeraman yang sesuai dalam pengolahan minyak kelapa dengan penambahan ekstrak batang buah nanas untuk meningkatkan rendemen serta mengetahui kualitas minyak yang dibuat dengan penambahan ekstrak batang buah nanas melalui penyimpanan selama 0, 2, 4, dan 6 minggu. Hasil yang diperoleh menunjukkan bahwa Perbandingan berat batang buah nanas dengan daging buah kelapa yang memberikan rendemen minyak tertinggi adalah perlakuan 8:2 dengan waktu pemeraman 12 jam yaitu sebesar 23,495\%. Kualitas minyak kelapa selama pengujian 6 minggu yaitu : kadar air $0,258 \%$; bilangan asam $1,343 \%$; bilangan peroksida 1,579 meq/1000g; dan asam lemak bebas $0,336 \%$.
\end{abstract}

Kata Kunci: batang buah nanas, minyak kelapa

\section{UTILIZATION PINEAPPLE STEM EXTRACT FOR QUALITY OF COCONUT OIL}

\begin{abstract}
Has done research utilization pineapple stem extract to the quality of coconut oil. Palm oil processing is still done traditionally by many people, especially people who live in rural areas. The existence of technological developments that coconut oil processed traditionally competes with palm oil on the market. To overcome this requires a method that can produce high quality oil with a long shelf life and provide a preferred scent. This study aims to determine the weight ratio of the stem pineapple and coconut meat and curing the appropriate time in the processing of coconut oil with the addition of pineapple stem extract to increase the yield and determine the quality of oil that is made with the addition of pineapple stem extract through storage for $0,2,4$, and 6 weeks. The results showed that the ratio by weight rod with a pineapple coconut meat that gives the highest oil yield was treated 8:2 with 12 hour curing time that is equal to $23.495 \%$.
\end{abstract}

The quality of coconut oil for 6 weeks of testing namely: the water content of $0.258 \%, 1.343 \%$ acid numbers; numbers meq $/ 1000 \mathrm{~g}$ peroxide 1.579 , and $0.336 \%$ free fatty acids.

Keywords: pineapple stem, palm oil

\section{PENDAHULUAN}

\section{Latar Belakang}

Indonesia merupakan salah satu Negara yang memiliki luas dan hasil kelapa (Cocos nucifera, L) terbesar di dunia. Sulawesi Utara termasuk salah satu daerah penghasil kelapa di Indonesia. Tanaman kelapa mempunyai manfaat yang cukup besar di dalam kehidupan manusia sehari-hari (Soedjianto dan Sianipar, 1981). Tanaman kelapa sering disebut sebagai pohon kehidupan, karena sangat bermanfaat bagi kehidupan manusia. Salah satu produk kelapa 
adalah minyak kelapa (Suhardiyono, 1998). Menurut Ketaren (1986), buah kelapa merupakan salah satu sumber minyak yang sangat penting di Indonesia.

Minyak kelapa dapat diperoleh dari daging buah kelapa segar atau dari kopra. Pengolahan minyak kelapa masih banyak dilakukan secara tradisional oleh masyarakat, khususnya masyarakat yang tinggal di pedesaan. Adanya perkembangan teknologi minyak kelapa yang diolah secara tradisional bersaing dengan minyak kelapa yang ada di pasaran. Untuk mengatasi hal ini diperlukan metode yang dapat menghasilkan minyak yang berkualitas dengan daya simpan yang lama dan memberikan aroma yang disukai. Pengolahan minyak kelapa dengan penambahan ekstrak batang buah nanas dilakukan dengan cara menimbang masingmasing sebanyak 900, 800 dan 700 g lalu ke dalam wadah tersebut ditambahkan air (70 $\left.{ }^{\circ} \mathrm{C}\right)$ dengan perbandingan 1:1 kemudian dicampur, diperas dan disaring untuk memperoleh santan. kemudian didiamkan dengan perlakuan selama 6 jam, 12 jam dan 18 jam kemudian dipisahkan skim (lapisan bawah) dan krim (lapisan atas). Selanjutnya disentrifuse pada $3000 \mathrm{rpm}$ selama 10 menit dan dipanaskan pada suhu $60{ }^{\circ} \mathrm{C}$ selama \pm 10 menit. Minyak yang dihasilkan dihitung rendemennya dan dianalisis kualitas minyak pada 0 minggu, 2 minggu, 4 minggu dan 6 minggu.

Salah satu metode yang dapat meningkatkan rendemen maupun kualitas minyak adalah dengan menghidrolisis proteinnya sehingga minyak dapat lepas dari ikatan lipoprotein. Menurut Sudarmadji et al., (1989) bahwa hidrolisis protein dapat dilakukan dengan menambahkan larutan asam, basa atau dengan enzim. Enzim proteolitik merupakan enzim yang dapat menghidrolisis protein menjadi unsur-unsur penyusunnya. Molekul enzim dapat meningkatkan kecepatan reaksi kimia. Salah satu enzim proteolitik yang sering digunakan dalam pengolahan pangan adalah enzim bromelin (Jacob dalam Suprayitno, 1998).

Menurut Whitaker (1991), tanaman nanas mengandung enzim bromelin, yaitu suatu enzim proteolitik yang dapat mengkatalisis reaksi hidrolisis suatu ikatan peptida dari protein. Bagian buah yang lain seperti batang, kulit dan tangkai nanas juga mengandung enzim bromelin. Menurut
Yandri dalam Kambey (2006), melaporkan bahwa kandungan enzim bromelin pada tanaman nanas antara lain terdapat pada buah nanas dengan aktivitas spesifik tertinggi yaitu $62,5 \mathrm{U} / \mathrm{mg}$; sedangkan pada batang nanas $27,3 \mathrm{U} / \mathrm{mg}$ dan pada kulit nanas 32,2 U/mg. Pemanfaatan tanaman nanas pada umumnya hanya terbatas pada daging buah nanas, sedangkan batang buah nanas tidak dimanfaatkan oleh masyarakat dan hanya dibuang sebagai limbah, padahal limbah batang buah nanas mengandung enzim bromelin dengan aktivitas cukup tinggi yang dapat dimanfaatkan dalam pengolahan minyak kelapa (Wikipedia, 2006).

Berdasarkan penelitian yang dilakukan oleh Syaukani dan Khalid (1998) bahwa penambahan enzim bromelin dari buah nanas pada pengolahan minyak kelapa tradisional berpengaruh terhadap kualitas minyak dan variasi waktu pemeraman santan krim dari minyak yang dihasilkan. Pengolahan minyak kelapa dengan proses enzimatis juga sudah pernah dilakukan sebelumnya oleh Sangi (2006) yaitu dengan menggunakan kulit nanas. Perlakuan yang memberikan hasil optimum yaitu pada waktu pemeraman 12 jam dengan perbandingan 8:2. Hasil minyak yang diperoleh yaitu $21.80 \%$. Sedangkan pengolahan minyak kelapa dengan penambahan ekstrak batang buah nanas yang mengandung enzim bromelin belum pernah dilakukan.

Berdasarkan informasi tersebut, telah dilakukan penelitian mengenai pengolahan minyak kelapa dengan penambahan ekstrak batang buah nanas. Pengolahan minyak kelapa dengan penambahan ekstrak batang buah nanas diharapkan dapat meningkatkan rendemen maupun kualitas minyak yang dihasilkan. Minyak yang dihasilkan kemudian di analisis kadar air, bilangan asam, bilangan peroksida, asam lemak bebas dan kadar minyak. Analisis kualitas minyak dilakukan selama 6 minggu untuk mengetahui daya simpan dari minyak tersebut. 


\section{METODOLOGI PENELITIAN}

\section{Prosedur Penelitian}

\section{Pengolahan Minyak Kelapa dengan Penambahan Ekstrak Batang Buah nanas}

Pengolahan minyak kelapa dengan penambahan ekstrak batang buah nanas dilakukan dengan cara sebagai berikut :

1. Daging buah kelapa diparut kemudian ditimbang masing-masing sebanyak 900 $\mathrm{g}, 800 \mathrm{~g}$ dan $700 \mathrm{~g}$ lalu ke dalam wadah tersebut ditambahkan air $\left(70{ }^{\circ} \mathrm{C}\right)$ dengan perbandingan 1:1 (900 g kelapa parut/900 $\mathrm{mL}$ air, $800 \mathrm{~g}$ kelapa parut $/ 800 \mathrm{~mL}$ air dan 700 g kelapa parut $/ 700 \mathrm{~mL}$ air) kemudian dicampur, diperas dan disaring untuk memperoleh santan.

2. Batang buah nanas terlebih dahulu dibersihkan lalu dipotong kecil-kecil, ditimbang masing-masing sebanyak 100 g, $200 \mathrm{~g}$ dan $300 \mathrm{~g}$ kemudian diblender, diperas dan disaring untuk memperoleh ekstrak batang buah nanas.

3. Untuk kontrol dibuat tanpa penambahan batang buah nanas

4. Santan dan sari ekstrak batang buah nanas dicampur kemudian didiamkan dengan perlakuan selama 6 jam, 12 jam dan 18 jam kemudian dipisahkan skim (lapisan bawah) dan krim (lapisan atas).

5. Krim kemudian disentrifuse pada 3000 rpm selama 10 menit dan dipanaskan pada suhu $60^{\circ} \mathrm{C}$ selama \pm 10 menit.

6. Minyak yang dihasilkan dihitung rendemennya dan dianalisis kualitas minyak pada 0 minggu, 2 minggu, 4 minggu dan 6 minggu.

\section{Rendemen Minyak (Sudarmadji et al., 1984)}

Rendemen minyak diperoleh dari berat minyak yang dihasilkan dibagi berat daging buah kelapa parut yang digunakan.

Rendemen minyak $(\%)=$

$$
\frac{\text { Berat minyak }(\mathrm{g})}{\text { Berat daging kelapa parut }(\mathrm{g})}{ }^{\mathrm{x}-100}
$$

\section{Analisis Kualitas Minyak}

Kualitas minyak kelapa dapat ditentukan dengan beberapa metode yaitu:
Kadar Air (Sudarmadji et al., 1984)

Penentuan kadar air minyak dapat dilakukan dengan metode oven. Metode oven : sampel ditimbang sebanyak $\pm 5 \mathrm{~g}$ dalam cawan porselin, dipanaskan dalam oven pada temperatur $105{ }^{\circ} \mathrm{C}$ selama 3 jam kemudian didinginkan dalam desikator lalu ditimbang. Penimbangan dilakukan sampai mencapai berat konstan.

$$
\begin{aligned}
& \text { Kadar Air (\%) }=\frac{A-B}{A} \times 100 \% \\
& \begin{array}{c}
\text { Dimana A } \\
\text { dipanaskan }
\end{array} \text { Berat minyak sebelum } \\
& \text { B }=\text { Berat minyak setelah } \\
& \text { dipanaskan. }
\end{aligned}
$$

\section{Bilangan Asam (Sudarmadji et al., 1984)}

Minyak yang diperoleh setelah penambahan batang buah nanas ditimbang sebanyak $\pm 5 \mathrm{~g}$ dalam labu Erlenmeyer dan ditambahkan $50 \mathrm{~mL}$ etanol $96 \%$ kemudian dipanaskan selama 10 menit dalam penangas air sambil diaduk selanjutnya ditambahkan 3 tetes indikator phenolphtalein (pp) lalu dititrasi dengan larutan $\mathrm{KOH} 0,05 \mathrm{~N}$ sampai warna merah jambu tercapai dan tidak hilang selama 30 detik. Hal yang sama dilakukan juga terhadap minyak kontrol.

Bilangan Asam =

$$
\frac{\mathrm{mL} \mathrm{KOH} \times \mathrm{N} \mathrm{KOH} \mathrm{x} \mathrm{56,1}}{\text { Berat sampel }(\mathrm{g})}
$$

\section{Bilangan Peroksida (Sudarmadji et al., 1984)}

Minyak yang diperoleh setelah penambahan batang buah nanas ditimbang sebanyak $\pm 5 \mathrm{~g}$ dalam labu Erlenmeyer 250 $\mathrm{mL}$ bertutup dan ditambahkan $30 \mathrm{~mL}$ larutan asam asetat - kloroform (3:2), lalu diaduk sampai semua bahan larut. Selanjutnya, kemudian ditambahkan $0,5 \mathrm{~mL}$ larutan KI jenuh. Didiamkan 1 menit kadang kala digoyang kemudian ditambahkan $30 \mathrm{~mL}$ aquades. Kemudian dititrasi dengan larutan $0,01 \mathrm{~N} \mathrm{Na}_{2} \mathrm{~S}_{2} \mathrm{O}_{3}$ hingga warna kuning hampir hilang. Ditambahkan 0,5 mL larutan pati $1 \%$ dititrasi hingga larutan warna biru mulai hilang. Angka peroksida dinyatakan dalam mili-equivalen dari peroksida dalam setiap $1000 \mathrm{~g}$ sampel. 
Bilangan Peroksida $(\%)=$

$$
\mathrm{mL} \mathrm{Na}_{2} \mathrm{~S}_{2} \mathrm{O}_{3} \times \mathrm{N} \mathrm{Na}_{2} \mathrm{~S}_{2} \mathrm{O}_{3} \times 1000
$$

Berat sampel (g)

\section{Asam Lemak Bebas (Sudarmadji et al., 1984)}

Minyak kelapa ditimbang sebanyak \pm 5 g dalam labu Erlenmeyer $250 \mathrm{~mL}$. Ke dalam sampel ditambahkan $50 \mathrm{~mL}$ etanol netral yang panas, dan $2 \mathrm{~mL}$ indikator phenolphtalein. Sampel dititrasi dengan 0.05 $\mathrm{N} \mathrm{NaOH}$ yang telah distandarisasi sampai warna merah jambu dan tidak hilang selama 30 detik. Asam lemak bebas dinyatakan sebagai \% FFA.

$\% \mathrm{FFA}=$

$\mathrm{mL} \mathrm{NaOH}$ x N NaOH xMM $\mathrm{Msam}_{\text {as }}$ 00

Berat sampel $\mathrm{x}$

\section{Analisis Data}

Semua eksperimen dilakukan dua kali pengulangan dan data yang diperoleh di analisis dengan Rancangan Acak Lengkap menggunakan program Statistical Analysis System (SAS) versi 6.12.

\section{HASIL DAN PEMBAHASAN}

\section{Minyak Kelapa}

Minyak kelapa yang dihasilkan dari pengolahan daging buah kelapa dengan ekstrak batang buah nanas pada perlakuan dengan perbandingan 9:1, 8:2, dan 7:3 pada pemeraman 6 jam, 12 jam, dan 18 jam adalah berwarna kuning muda dan jernih. Warna yang nampak pada minyak kelapa kemungkinan adalah zat warna alamiah dari batang buah nanas. Hasil rendemen minyak dapat dilihat pada tabel 1 .

Tabel 1. Hasil Rendemen Minyak Kelapa Pada Pemeraman 6, 12, dan 18 jam.

\begin{tabular}{|c|c|c|c|}
\hline \multirow{2}{*}{ Perlakuan } & \multicolumn{3}{|c|}{ Rendemen Minyak (\%) } \\
\cline { 2 - 4 } & Pemeraman 6 jam & Pemeraman 12 jam & Pemeraman 18 jam \\
\hline \multirow{2}{*}{ Kontrol } & $\begin{array}{c}18,357 \pm 1954 \\
\mathrm{c}, \mathrm{a}, \mathrm{b}\end{array}$ & $\begin{array}{c}18,538 \pm 1,935 \mathrm{c}, \mathrm{a}, \mathrm{b} \\
22,382 \pm 0,385 \\
\mathrm{a}\end{array}$ \\
\hline $9: 1$ & $16,409 \pm 2,925 \mathrm{c}, \mathrm{d}, \mathrm{b}$ & $\begin{array}{c}20,919 \pm 0,740 \\
\mathrm{a}, \mathrm{b}\end{array}$ & $\begin{array}{c}18,277 \pm 3,474 \mathrm{c}, \mathrm{a}, \mathrm{b} \\
\mathrm{a}\end{array}$ \\
\hline $8: 2$ & $14,686 \pm 4,475 \mathrm{c}, \mathrm{d}, \mathrm{e}$ & $\begin{array}{c}23,495 \pm 1,297 \\
\mathrm{a}\end{array}$ & $\begin{array}{c}11,512 \pm 2,193 \\
\mathrm{~d}, \mathrm{e}\end{array}$ \\
\hline $7: 3$ & $19,500 \pm 1,881 \mathrm{c}, \mathrm{a}, \mathrm{b}$ & $\begin{array}{c}15,428 \pm 2,205 \\
\mathrm{c}, \mathrm{d}, \mathrm{e}, \mathrm{b}\end{array}$ & $\begin{array}{c}10,596 \pm 4,052 \\
\mathrm{e}\end{array}$ \\
\hline
\end{tabular}

Keterangan : angka dengan huruf berbeda pada kolom yang sama menunjukkan berbeda nyata pada $\alpha=0,05$

Berdasarkan hasil pada tabel 1 yang diperoleh bahwa rendemen minyak yang dihasilkan berkisar 10,596 - 23,495\%. Rendemen minyak tertinggi terdapat pada perlakuan dengan perbandingan 8:2 pada pemeraman 12 jam yaitu sebesar $23,495 \%$, sedangkan rendemen minyak yang terendah $10,596 \%$ terdapat pada perlakuan dengan perbandingan 7:3 pada pemeraman 18 jam. Semakin tinggi rendemen minyak, maka semakin banyak minyak yang dihasilkan dari santan yang digunakan untuk mengekstrak minyak.

Dilihat dari rendemen minyak yang dihasilkan maka metode yang efektif atau baik digunakan untuk mengekstrak minyak adalah pada perlakuan dengan perbandingan 8:2 pada pemeraman 12 jam. Pada pemeraman 6 jam, minyak kelapa sampel dengan perbandingan 7:3 menghasilkan rendemen minyak yang lebih tinggi dari minyak kelapa sampel dengan perbandingan 8:2 dan 9:1. Hal ini kemungkinan disebabkan oleh kecepatan reaksi enzim bromelin pada sampel minyak kelapa dengan perbandingan 7:3 lebih besar dibandingkan dengan minyak kelapa sampel dengan perbandingan 8:2 dan 9:1. Pada pemeraman 12 jam, minyak kelapa sampel dengan perbandingan 9:1 dan 8:2 terjadi peningkatan rendemen. Peningkatan 
kadar minyak kemungkinan disebabkan aktivitas dari enzim bromelin yang masih bekerja. Sedangkan pada pemeraman 18 jam minyak kelapa sampel dengan perbandingan 8:2 dan 9:1 terjadi penurunan rendemen, hal ini kemungkinan disebabkan aktivitas dari enzim bromelin sudah mencapai maksimal pada pemeraman 12 jam, sedangkan minyak kelapa sampel dengan perbandingan 7:3 terjadi penurunan rendemen pada pemeraman 12 jam dan 18 jam, hal ini kemungkinan disebabkan aktivitas dari enzim bromelin sudah mencapai maksimal pada pemeraman 6 jam.

Pada pemeraman 12 jam, sampel minyak kelapa dengan perbandingan 8:2 menghasilkan rendemen minyak yang lebih tinggi dibandingakan sampel minyak kelapa dengan pebandingan 7:3 dan 9:1. Pada konsentrasi substrat (berat daging buah kelapa) yang rendah, kecepata reaksinya tergantung pada konsentrasi substrat itu sendiri. Pada konsentrasi substrat yang tinggi,

kecepatan reaksinya tidak lagi tergantung pada konsentrasi substrat itu sendiri (kecepatan reaksinya tidak dipengaruhi lagi oleh pertambahan konsentrasi substrat) karena semua bagian aktif enzim bromelin telah dipenuhi leh substrat atau telah jenuh dengan substrat. Pada konsentrasi substrat tertentu kecepatan reaksi bertambah dengan bertamabahnya konsentrasi enzim, hal ini disebabkan karena semakin banyak substrat yang dapat berhubungan dengan bagian aktif enzim bromelin sehingga menyebabkan kecepatan reaksinya semakin besar dan jumlah hasil reaksinyapun bertambah.

\section{Analisis Kadar Air}

Hasil analisis kadar air dari minyak kelapa yang dihasilkan selama penyimpanan $0,2,4$, dan 6 minggu dapat dilihat pada tabel 2.

Tabel 2. Hasil Analisis Kadar Air Minyak Kelapa pada Penyimpanan 0, 2, 4, dan 6 minggu.

\begin{tabular}{|c|c|c|}
\hline \multirow{2}{*}{$\begin{array}{c}\text { Masa } \\
\text { Penyimpanan }\end{array}$} & Kontrol & $\begin{array}{c}\text { Kengandung Ekstrak batang buah } \\
\text { nanas }\end{array}$ \\
\cline { 2 - 3 } & $0,125 \pm 0,033 \mathrm{~d}$ & $0,154 \pm 0,013 \mathrm{c}, \mathrm{d}$ \\
\hline 0 minggu & $0,188 \pm 0,028 \mathrm{c}, \mathrm{b}$ & $0,199 \pm 0,002 \mathrm{~b}$ \\
\hline 2 minggu & $0,194 \pm 0,015 \mathrm{c}, \mathrm{b}$ & $0,217 \pm 0,001 \mathrm{a}, \mathrm{b}$ \\
\hline 4 minggu & $0,207 \pm 0,019 \mathrm{~b}$ & $0,258 \pm 0,014 \mathrm{a}$ \\
\hline 6 minggu &
\end{tabular}

Keterangan : angka dengan huruf berbeda pada kolom yang sama menunjukkan berbeda nyata pada $\alpha=0,05$

Penentuan kadar air penting dilakukan, sebab air yang terkandung dalam minyak dapat mempengaruhi kualitas dari minyak tersebut. Semakin rendah kadar air yang terkandung dalam minyak semakin baik kualitasnya.

Berdasarkan tabel 2, hasil analisa kadar air dari minyak yang mengandung ekstrak batang buah nanas lebih tinggi dibandingkan dengan minyak pada kontrol (tidak mengandung ekstrak batang buah nanas). Kadar air yang tinggi pada minyak yang mengnadung ekstrak batang buah nanas kemungkinan disebabkan oleh adanya sejumlah air yang terdapat dalam minyak yang diduga berasal dari penambahan air pada waktu mengekstrak batang buah nanas.
Kadar air yang diperoleh pada penelitian ini berkisar antara $0,125-0,258$ $\%$. Kadar air tertinggi terdapat pada minyak yang mengandung ekstrak batang buah nanas pada penyimpanan 6 minggu yaitu sebesar $0,258 \%$, sedangkan kadar air terendah terdapat pada minyak kontrol pada penyimpanan 0 minggu yaitu sebesar 0,125 $\%$. Kadar air tertinggi yang diperoleh pada penelitian ini masih sesuai dengan standar yang ditetapkan oleh Standar Industri Indonesia (SII) yaitu sebesar 0,5\%. Jadi kadar air yang dihasilkan cukup baik karena berada dibawah standar mutu yang telah ditetapkan.

Kadar air berhubungan dengan reaksi hidrolisis dari lemak. Jika dalam lemak atau 
minyak terdapat air maka minyak tersebut akan terhidrolisis sehingga menghasilkan asam lemak bebas dan gliserol. Reaksi hidrolisis dari minyak dapat dilihat pada gambar berikut:

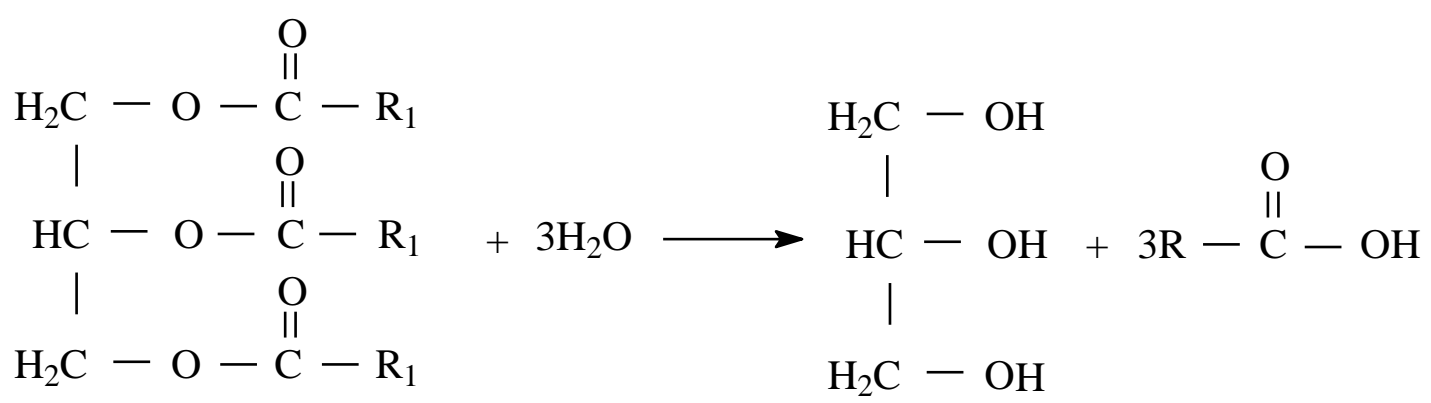

Trigliserida

Gliserol

Asam Lemah

Tabel 3. Hasil Analisis Bilangan Asam Minyak Kelapa yang Diperoleh pada Penyimpanan $0,2,4$, dan 6 minggu.

\begin{tabular}{|c|c|c|}
\hline \multirow{2}{*}{$\begin{array}{c}\text { Masa } \\
\text { Penyimpanan }\end{array}$} & Kontrol & $\begin{array}{c}\text { Bengandung Ekstrak batang buah } \\
\text { nanas }\end{array}$ \\
\cline { 2 - 3 } & $0,527 \pm 0,061 \mathrm{~d}$ & $1,151 \pm 0,144 \mathrm{~b}$ \\
\hline 0 minggu & $0,580 \pm 0,006 \mathrm{c}, \mathrm{d}$ & $1,221 \pm 0,057 \mathrm{a}, \mathrm{b}$ \\
\hline 2 minggu & $0,661 \pm 0,079 \mathrm{c}, \mathrm{d}$ & $1,237 \pm 0,042 \mathrm{a}, \mathrm{b}$ \\
\hline 4 minggu & $0,722 \pm 0,054 \mathrm{c}$ & $1,343 \pm 0,103 \mathrm{a}$ \\
\hline 6 minggu &
\end{tabular}

Keterangan : angka dengan huruf berbeda pada kolom yang sama menunjukkan berbeda nyata pada $\alpha=0,05$

Jika minyak tersebut banyak mengandung air, kemungkinan besar asam lemak bebas minyak akan besar pula, akibatnya kualitas minyak tersebut akan menururn. Reaksi hidrolisis akan mengakibatkan kerusakan minyak atau lemak sehingga menghasilkan flavour dan bau tengik pada minyak tersebut (Ketaren, 1986).

\section{Bilangan Asam}

Bilangan asam penting dilakukan, yaitu untuk mengukur jumlah asam lemak bebas yang terdapat dalam minyak atau lemak (Ketaren, 1986). Hasil analisis bilangan asam dari minyak kelapa yang dihasilkan selama penyimpanan $0,2,4$, dan 6 minggu dapat dilihat pada tabel 3 .

Tabel 3 menyajikan data bilangan asam minyak selama masa penyimpanan 0,2 , 4, dan 6 minggu. Berdasarkan data tersebut dapat dilihat bahwa bilangan asam dari minyak yang mengandung ekstrak batang buah nanas lebih tinggi dibandingkan dengan minyak kontrol (tidak mengandung ekstrak batang buah nanas). Hal ini disebabkan oleh tingginya kadar air dari minyak tersebut. Adanya air dalam minyak membuat minyak mudah terhidrolisis menjadi gliserol dan asam lemak. Hidrolisis minyak dapat disebabkan adanya sejumlah air dalam minyak, sehingga mempengaruhi bilangan asam minyak. Semakin tinggi kadar air dalam minyak, semakin tinggi pula bilangan asamnya. Proses hidrolisis dapat dipengaruhi oleh lamanya waktu penyimpanan minyak. Semakin lama minyak disimpan, kemungkinan minyak terhidrolisis akan semakin besar.

Bilangan asam yang diperoleh pada penelitian ini berkisar antara 0,527 - 1,343 $\%$. Bilangan asam terendah terdapat pada minyak kontrol pada penyimpanan 0 minggu yaitu sebesar $0,527 \%$, sedangkan bilangan asam tertinggi terdapat pada minyak yang mengandung ekstrak batang buah nanas pada penyimpanan 6 minggu yaitu sebesar 1,343 
$\%$. Bilangan asam minyak pada penyimpanan 0 minggu lebih rendah daripada bilangan asam minyak pada penyimpanan 2,4 , dan 6 minggu, hal ini dapat disebabkan pada minggu ke-0 minyak belum mengalami proses hidrolisis sehingga bilangan asamnya lebih rendah dibandingkan dengan bilangan asam minyak pada penyimpanan 2,4 , dan 6 minggu. Jumlah maksimum bilangan asam minyak kelapa yang tergolong berkualitas baik menurut Standar Industri Indonesia (SII) adalah $5 \%$. Bilangan asam dari minyak yang diperoleh pada penelitian ini masih dibawah standar mutu yang telah ditetapkan oleh SII sehingga minyak tersebut tergolong berkualitas baik.

\section{Bilangan Peroksida}

Bilangan peroksida adalah nilai terpenting untuk menentukan derajat kerusakan pada minyak atau lemak. Asam lemak tidak jenuh dapat mengikat oksigen pada ikatan rangkapnya sehingga membentuk peroksida (Ketaren, 1986). Hasil analisis bilangan peroksida dari minyak kelapa yang dihasilkan selama penyimpanan $0,2,4$, dan 6 minggu dapat dilihat pada tabel 4.

Tabel 4. Hasil Analisis Bilangan Peroksida Minyak Kelapa yang Diperoleh pada Penyimpanan $0,2,4$, dan 6 minggu.

\begin{tabular}{|c|c|c|}
\hline \multirow{2}{*}{$\begin{array}{c}\text { Masa } \\
\text { Penyimpanan }\end{array}$} & \multicolumn{2}{|c|}{ Bilangan Peroksida (meq/1000g) } \\
\cline { 2 - 3 } & Kontrol & $\begin{array}{c}\text { Mengandung Ekstrak batang buah } \\
\text { nanas }\end{array}$ \\
\hline 0 minggu & $0,960 \pm 0,122 \mathrm{c}$ & $1,808 \pm 0,501 \mathrm{a}$ \\
\hline 2 minggu & $1,011 \pm 0,092 \mathrm{c}, \mathrm{b}$ & $1,954 \pm 0,012 \mathrm{a}$ \\
\hline 4 minggu & $1,612 \pm 0,093 \mathrm{a}$ & $1,749 \pm 0,177 \mathrm{a}$ \\
\hline 6 minggu & $1,872 \pm 0,125 \mathrm{a}$ & $1,192 \pm 0,415 \mathrm{a}, \mathrm{b}$ \\
\hline
\end{tabular}

Keterangan : angka dengan huruf berbeda pada kolom yang sama menunjukkan berbeda nyata pada $\alpha=0,05$

Tabel 4 menyajikan data bilangan peroksida minyak selama masa penyimpanan 0, 2, 4, dan 6 minggu. Berdasarkan data tersebut dapat dilihat bahwa bilangan peroksida dari minyak kontrol cenderung meningkat selama masa penyimpanan, sedangkan bilangan peroksida dari minyak yang mengandung ekstrak batang buah nanas cenderung tidak berubah atau menurun selama masa penyimpanan 6 minggu. Hal ini diduga disebabkan oleh adanya senyawa antioksidan dari batang buah nanas khususnya senyawa zat warna alamiah (karoten) yang ikut larut ke dalam minyak. Adanya senyawa karoten dalam minyak ditandai dengan warna kuning, yang intensitas warnanya tergantung pada konsentrasi ekstrak batang buah nanas yang digunakan.

Bilangan peroksida menyatakan jumlah ekivalen hidroperoksida yang terbentuk setiap $1000 \mathrm{~g}$ sampel. Hidroperoksida terbentuk dari reaksi radikal bebas peroksida dengan asam lemak tak jenuh pada minyak. Reaksi kimia yang terjadi pada penentuan bilangan peroksida dapat dilihat pada persamaan reaksi sebagai berikut:

$$
\begin{array}{ll}
\mathrm{ROOH}+2 \mathrm{H}^{+}+2 \mathrm{KI} & \longrightarrow \mathrm{I}_{2}+\mathrm{ROH} \\
+\mathrm{H}_{2} \mathrm{O}+2 \mathrm{~K}^{+} & \longrightarrow \mathrm{Na}_{2} \mathrm{~S}_{4} \mathrm{O}_{6}
\end{array}
$$

Reaksi tersebut didasarkan pada reaksi gugus hidroperoksida $(\mathrm{ROOH})$ dengan ion iodida $\left(\mathrm{I}^{-}\right)$. Jumlah iodin $\left(\mathrm{I}_{2}\right)$ yang dibebaskan sebanding dengan konsentrasi hidroperoksida yang ada. Iodin yang terbentuk dapat diketahui jumlahnya melalui titrasi natrium tiosulfat menggunakan indikator pati. Kalium iodida (KI) digunakan sebagai reduktor untuk mereduksi hidroperoksida, dan bila bereaksi akan terbentuk $I_{2}$ bebas (Asa dalam Nurlina, 2007).

\section{Asam Lemak Bebas}

Asam lemak bebas (FFA) penting dilakukan sebab tingginya asam lemak bebas dapat mempengaruhi cita rasa dan bau pada 
minyak sehingga menyebabkan penurunan kualitas dari minyak tersebut. Semakin tinggi nilai FFA maka semakin banyak asam lemak bebas yang terdapat dalam minyak tersebut. (Ketaren, 1986). Hasil analisis asam lemak bebas dari minyak kelapa yang dihasilkan selama penyimpanan $0,2,4$, dan 6 minggu dapat dilihat pada tabel 5.

Tabel 5. Hasil Analisis Asam Lemak Bebas Minyak Kelapa yang Diperoleh pada Penyimpanan $0,2,4$, dan 6 minggu.

\begin{tabular}{|c|c|c|}
\hline \multirow{2}{*}{$\begin{array}{c}\text { Masa } \\
\text { Penyimpanan }\end{array}$} & \multicolumn{2}{|c|}{ Asam Lemak Bebas (\%) } \\
\cline { 2 - 3 } & Kontrol & $\begin{array}{c}\text { Mengandung Ekstrak batang } \\
\text { buah nanas }\end{array}$ \\
\hline 0 minggu & $0,158 \pm 0,006 \mathrm{c}$ & $0,279 \pm 0,030 \mathrm{~b}$ \\
\hline 2 minggu & $0,163 \pm 0,008 \mathrm{c}$ & $0,319 \pm 0,001 \mathrm{a}, \mathrm{b}$ \\
\hline 4 minggu & $0,168 \pm 0,008 \mathrm{c}$ & $0,320 \pm 0,016 \mathrm{a}, \mathrm{b}$ \\
\hline 6 minggu & $0,174 \pm 0,021 \mathrm{c}$ & $0,336 \pm 0,029 \mathrm{a}$ \\
\hline
\end{tabular}

Keterangan : angka dengan huruf berbeda pada kolom yang sama menunjukkan berbeda nyata pada $\alpha=0,05$

Tabel 5 menyajikan data asam lemak bebas minyak selama masa penyimpanan 6 minggu. Berdasarkan data tersebut dapat dilihat bahwa kadar asam lemak bebas pada minyak yang mengandung ekstrak batang buah nanas lebih tinggi dibandingkan dengan minyak kontrol (tidak mengandung ekstrak batang buah nanas), hal ini disebabkan oleh tingginya kadar air dari minyak tersebut. Asam lemak bebas terbentuk karena proses hidrolisis. Hidrolisis minyak dapat disebabkan oleh adanya sejumlah air yang terdapat dalam minyak. Proses hidrolisis dapat dipengaruhi oleh lamanya waktu penyimpanan minyak. Semakin lama minyak disimpan, kemungkinan minyak terhidrolisis akan semakin besar.

Kadar asam lemak bebas yang diproleh pada penelitian ini berkisar antara $0,158-0,336 \%$. Kadar asam lemak bebas terendah terdapat pada minyak kontrol pada penyimpanan 0 minggu yaitu sebesar 0,158 $\%$, sedangkan kadar asam lemak bebas tertinggi terdapat pada minyak yang mengandung ekstrak batang buah nanas pada penyimpanan 6 minggu yaitu sebesar 0,336 $\%$. Kadar asam lemak bebas minyak pada penyimpanan 0 minggu lebih rendah daripada kadar asam lemak bebas minyak pada penyimpanan 2, 4, dan 6 minggu, hal ini dapat disebabkan pada minggu ke-0 minyak belum mengalami proses hidrolisis sehingga kadar asam lemak bebasnya lebih rendah dibandingkan dengan kadar asam lemak bebas minyak pada penyimpanan 2, 4, dan 6 minggu. Jumlah maksimum kadar asam lemak bebas pada minyak kelapa menurut Standar Industri Indonesia (SII) adalah $5 \%$. Kadar asam lemak bebas dari minyak yang diperoleh pada penelitian ini masih dibawah standar mutu yang telah ditetapkan oleh SII sehingga minyak tersebut tergolong berkualitas baik.

\section{KESIMPULAN DAN SARAN}

\section{Kesimpulan}

Berdasarkan data yang diperoleh pada penelitian ini dapat disimpulkan bahwa:

1. Perbandingan berat batang buah nanas dengan daging buah kelapa yang memberikan rendemen minyak tertinggi adalah perlakuan 8:2 dengan waktu pemeraman 12 jam yaitu sebesar 23,495 $\%$.

2. Kualitas minyak kelapa selama pengujian 6 minggu yaitu : kadar air 0,258\%; bilangan asam $1,343 \%$; bilangan peroksida $1,579 \mathrm{meq} / 1000 \mathrm{~g}$; dan asam lemak bebas $0,336 \%$.

\section{Saran}

Perlu dilakukan penelitian lebih lanjut tentang komposisi zat-zat yang terdapat pada minyak kelapa yang dibuat dengan penambahan ekstrak batang buah nanas. 


\section{DAFTAR PUSTAKA}

Kambey, N. 2006. Pengolahan Minyak Kelapa dengan Penambahan Enzim Bromelin dari kulit Nanas (Ananas comosus L). [Skripsi]. FMIPA UNSRAT, Manado.

Ketaren, S. 1986. Pengantar Teknologi Minyak dan Lemak Pangan. Universitas Indonesia Press, Jakarta.

Nurlina. 2007. Pemanfaatan Ekstrak Umbi Wortel sebagai Sumber Enzim Proteolitik dan Senyawa Antioksidan dalam Produksi Minyak Kelapa. [Skripsi]. FMIPA UNSRAT, Manado.

Poedjiadi, A. 1994. Dasar-dasar Biokimia. UI-Press, Jakarta.

Soedijanto dan Sianipar. 1981. Kelapa. Cv. Yasaguna, Jakarta.

Sudarmadji, S., Haryono, B., dan Suhardi. 1984. Prosedur Analisa untuk Bahan Makanan dan Pertanian. Liberty, Yogyakarta.

Sudarmadji, S., Haryono, B., dan Suhardi. 1989. Analisa Bahan Makanan dan Pertanian. Liberty, Yogyakarta.
Suprayitno, E. 1998. Ekstraksi Minyak Hati Ikan Cucut Menggunakan Enzim Bromelin.edisis\% 20VII.\%20Desem ber\% 201996/ekstraksi\%20minyak \%20hati\%20ikan.pdf [25 Juni 2007].

Syaukani, M dan Khalid, C. 1998. Teknologi Pengolahan Minyak Kelapa Secara Enzimatis Menggunakan Enzim Bromelin. $\quad$ hhtp://www.smunet.com/main.php?act+ai. [17 Juni 2007].

Whitaker, J.R. 1991. Principles of Enzymology for The Food Sciences. Marcel Dekker Inc, New York.

Wikipedia. 2006. Pokok Kelapa. http://ms.wikipedia.org/wiki/Pokok Kelapa [ 17 Juni 2007].

Wikipedia. 2006. Tanaman Nanas. http://www.id.wikipedia.org/wiki/n anas [ 17 Juni 2007].

Winarno, F.G. 2002. Kimia Pangan dan Gizi. Gramedia Pustaka Utama, Jakarta. 